\title{
Contemporary management of high-grade gliomas
}

\author{
Hao-Wen Sim $*, \ddagger 1$, Erin R Morgan ${ }^{\ddagger 1}$ \& Warren P Mason**,1 \\ ${ }^{1}$ Princess Margaret Cancer Centre, 610 University Avenue, Toronto, Ontario M5G 2M9, Canada \\ * Author for correspondence: hao-wen.sim@uhn.ca \\ ** Author for correspondence: warren.mason@uhn.ca \\ $\ddagger$ Both are co-primary authors
}

\section{Practice points}

- Molecular markers now have an established role in the diagnosis and management of high-grade glioma, and have been incorporated into the updated WHO 5th Edition Classification of Tumors of the Central Nervous System.

- There is new evidence to guide management of patients over 65 years of age with high-grade glioma. Most of these patients will benefit from short-course radiotherapy with concurrent and adjuvant temozolomide.

- For unselected patients with high-grade glioma, the role of bevacizumab is limited.

- Tumor-treating fields have shown efficacy in patients with newly diagnosed glioblastoma. However, it does not meet established benchmarks for cost-effectiveness and has not been widely adopted as a therapy for patients with this disease.

- Immunotherapeutics are under evaluation for high-grade glioma. We await the forthcoming results from randomized Phase III trials.

- Many targeted therapies have been evaluated for high-grade glioma, but so far have lacked clinical utility. Efforts incorporating novel strategies are ongoing.

High-grade gliomas, including glioblastoma, are the most common malignant brain tumors in adults. Despite intensive efforts to develop new therapies for these diseases, treatment options remain limited and prognosis is poor. Recently, there have been important advances in our understanding of the molecular basis of glioma, leading to refinements in our diagnostic and management approach. There is new evidence to guide the treatment of elderly patients. A multitude of new agents have been investigated, including targeted therapies, immunotherapeutics and tumor-treating fields. This review summarizes the key findings from this research, and presents a perspective on future opportunities to advance the field.

First draft submitted: 8 August 2017; Accepted for publication: 2 October 2017; Published online:

15 December 2017

Keywords: bevacizumab $\bullet$ drug development $\bullet$ elderly $\bullet$ high-grade glioma $\bullet$ immunotherapy $\bullet$ molecular biology - tumor-treating fields

High-grade gliomas, including glioblastoma (GBM), anaplastic astrocytoma (AA) and anaplastic oligodendroglioma $(\mathrm{AO})$, originate from the supporting neuroglial cells of the CNS. GBM, the most common and most aggressive of the primary brain tumors, typically presents in late adulthood. AA and AO affect a younger age group and generally have a more protracted clinical course. High-grade gliomas can be debilitating, owing to physical disability, cognitive impairment, personality change, depression and seizure disorder, and require complex multidisciplinary care.

For patients with newly diagnosed GBM, maximal safe resection followed by radiotherapy with concomitant and adjuvant temozolomide chemotherapy is the current standard of care. Median overall survival for patients with GBM remains poor and was 14.6 months in the landmark EORTC 26981/22981-NCIC CTG CE3 Phase III trial $[1,2]$. This same approach is used for patients with newly diagnosed AA, based on preliminary findings of the 'Concurrent and Adjuvant Temozolomide in Non-1p/19q Deleted Anaplastic Glioma' (CATNON) trial [3]. For patients with newly diagnosed AO, chemoradiotherapy with procarbazine, lomustine and vincristine (PCV) has demonstrable efficacy in Phase III trials $[4,5]$. However, due to the increased toxicity and treatment burden 
of PCV versus monthly temozolomide, many clinicians substitute temozolomide in this setting. Accordingly, a comparison of PCV against temozolomide is underway in the 'Concomitant and Adjuvant Temozolomide Versus PCV Chemotherapy in Patients With Anaplastic Glioma or Low Grade Glioma' (CODEL) trial (NCT00887146).

Tumor recurrence occurs in almost all patients. Options include repeat surgical debulking, radiotherapy, lomustine (CCNU), bevacizumab, etoposide and procarbazine. However, there is no global standard and prognosis is limited. Patients are encouraged to enroll in clinical trials to access novel therapies.

Clearly, there exists an unmet need for innovative approaches. In this review, we highlight important changes to the evidence base for high-grade glioma. We begin with a discussion of major updates, namely molecular neuropathology, the management of elderly patients, bevacizumab and tumor-treating fields (TTF). This is followed by an overview of clinical trials of immunotherapeutics and targeted therapies for high-grade gliomas. Finally, we offer our perspective on research priorities and speculate on the future directions of the field.

\section{Major updates}

Molecular biology of high-grade gliomas

There have been substantial advances in our understanding of the molecular aberrations found in malignant gliomas. Key discoveries include the isocitrate dehydrogenase (IDH) mutation, codeletion of the short arm of chromosome 1 and long arm of chromosome $19(1 \mathrm{p} 19 \mathrm{q})$ and $\mathrm{O}^{6}$-methylguanine-DNA methyltransferase (MGMT) gene promoter methylation. These have emerged as being important determinants of treatment response and survival. Consequently, they are now routinely tested and have become fundamental to glioma classification.

IDH catalyzes the oxidative decarboxylation of isocitrate to $\alpha$-ketoglutarate, and subsequently to the oncometabolite 2-hydroxyglutarate [6]. In turn, 2-hydroxyglutarate acts via a family of dioxygenases to impair epigenetic regulation and increase hypoxia-inducible factor $1-\alpha$. The prevalent $I D H 1 \mathrm{R} 132 \mathrm{H}$ mutation is detectable with immunohistochemistry in over $90 \%$ of cases [7]. IDH mutations can also be identified by sequencing $I D H 1$ codon 132 and $I D H 2$ codon 172 . These mutations are common in low-grade gliomas and secondary GBMs, and confer significantly improved prognosis [8].

The $1 \mathrm{p} 19 \mathrm{q}$ codeletion is an unbalanced reciprocal translocation that is a characteristic of oligodendrogliomas. Multiple studies have demonstrated the favorable prognostic and predictive utility of the $1 \mathrm{p} / 19 \mathrm{q}$ codeletion, although the biologic basis remains unclear. Specifically, in randomized Phase III trials evaluating chemoradiotherapy with PCV for AO, patients harboring the 1p19q codeletion derived greater benefit from PCV and lived substantially longer $[4,5]$. In contrast, partial 1p or 19q loss did not confer this significance.

MGMT gene promotor methylation causes epigenetic silencing of MGMT, which is necessary for DNA repair. Notably, based on review of randomized Phase III trials evaluating temozolomide in patients with GBM, those containing the MGMT gene promoter methylation obtained meaningful survival benefit from temozolomide, whereas those without the methylation did not [9]. Initially, MGMT status was assessed with immunohistochemistry and MGMT methylation-specific PCR; however, widespread clinical use was limited by numerous technical issues including poor reliability, reproducibility and the labor-intensive work [10,11]. Newer methods include bisulfite sequencing, pyrosequencing, high-resolution melt analysis and infinium methylation BeadChip, which have improved standardization and accuracy of MGMT testing [12,13].

In 2016, the WHO published the 5th Edition Classification of Tumors of the Central Nervous System [14]. This represents a seminal update, with the introduction of integrated diagnoses combining histology and molecular parameters for many entities. This incorporates the recently established prognostic and predictive information from IDH and $1 \mathrm{p} 19 \mathrm{q}$.

GBM is now subdivided into IDH wild-type (predominantly primary GBM, patients over 55 years of age, poor prognosis) and IDH-mutant entities (predominantly secondary GBM, younger patients, favorable prognosis). The diagnosis of $\mathrm{AO}$ requires IDH-mutant and 1p19q-codeleted status, whereas AA requires IDH-mutant and noncodeleted status. Importantly, both entities are IDH mutant; a glioma that is IDH wild-type with or without $1 \mathrm{p} 19 \mathrm{q}$ codeletion instead represents a genomically unstable GBM. In addition, 1p19q codeletion is mutually exclusive with TP53 mutation and ATRX inactivation [15]. Accordingly, a glioma that is IDH-mutant, TP53mutant and ATRX-inactivated is considered AA. Finally, the use of molecular parameters handles the problematic and indeterminate entity called anaplastic oligoastrocytoma, which was previously defined by a mixed histological pattern and was subject to poor interobserver agreement $[16,17]$. The combination of histology and molecular parameters effectively differentiates nearly all cases as either $\mathrm{AO}$ or AA. To facilitate clinical decision making, the 
current standard is to incorporate all the tissue-based information (histology, grade, molecular findings) into an integrated diagnosis, which is then reported to clinicians.

Molecular markers have significantly contributed to diagnostic precision in high-grade glioma, and yield important therapeutic implications. The next steps will be to improve understanding of clinical and molecular heterogeneity within glioma subtypes. Ongoing efforts include assessment of additional molecular markers, methylation profiling and a coordinated approach to histologic-molecular correlation as part of clinical trials.

\section{Treatment of high-grade gliomas in the elderly}

Although GBM is predominantly a disease of older adults, with a median age of diagnosis of 64 and an increasing number of patients diagnosed over the age of 70 [18], management of this disease in the elderly remains a particular challenge. Compared with younger patients, those over the age of 65 have shorter overall survival [19-21]. The EORTC 26981/22981-NCIC CE3 study excluded patients over 70 [1,2], and although a subgroup analysis showed a trend toward benefit in patients over 60 years old, the degree of benefit diminished with increasing age [19]. Elderly patients are also more susceptible to toxicities of treatment, including radiation-induced cognitive deficits [22] and chemotherapy side effects [23]. GBM in elderly patients also seems to be biologically more aggressive, with a very low incidence of favorable prognostic markers such as IDH mutations and the glioma cytosine-phosphate-guanine island methylator phenotype, although MGMT status does not seem to vary with age [24].

This has led to efforts to tailor treatment to this patient population through the use of modified radiation schedules and selective use of temozolomide chemotherapy. The French ANOCEF study demonstrated a median survival benefit of 12 weeks with radiotherapy versus supportive care alone in elderly patients [25]. Subsequently, Roa et al. [26] demonstrated similar survival in patients over age 60 who received short-course radiotherapy ( 40 Gy in 15 fractions) versus the conventional regimen (60 Gy in 30 fractions). Patients treated with short-course radiotherapy were less likely to require increased corticosteroid doses after completing treatment. The Nordic study [27] randomized patients over age 60 with newly diagnosed GBM to standard radiotherapy (60 Gy in 30 fractions), hypofractionated radiotherapy (34 Gy in 10 fractions) or temozolomide monotherapy. This trial demonstrated longer overall survival (OS) in patients over the age of 70 treated with hypofractionated versus standard radiotherapy. In addition, this study demonstrated improved survival in MGMT-methylated patients treated with temozolomide, whereas MGMT status did not influence response to radiotherapy. The NOA-08 study [28] demonstrated that temozolomide monotherapy was noninferior to radiotherapy alone in elderly patients with MGMT-methylated GBM, while patients with unmethylated tumors showed improved survival with radiotherapy alone. In addition, for the frail elderly with Karnofsky performance score < 70 , Pérez-Larraya et al. [29] showed that temozolomide monotherapy was a welltolerated regimen, and for the subgroup with MGMT-methylated GBM, survival outcomes were superior to historical control.

The role of combined chemoradiotherapy in elderly patients remained undefined until the recent publication of a Phase III trial, which randomized 562 elderly patients with GBM to either short-course radiotherapy alone (40 Gy in 15 fractions) or radiotherapy with concurrent temozolomide [30]. This trial demonstrated improved OS in patients treated with combined therapy (median 9.3 vs 7.6 months). Of note, survival benefit was greater in patients with MGMT-methylated tumors, although benefit was still observed in the unmethylated patient group.

Based on these studies, we can now propose a basic evidence-based approach for the first-line treatment of patients with GBM 65 years or older. For a minority of very fit, 'physiologically young' patients over 65 , it remains reasonable to propose standard chemoradiotherapy, with a discussion of the possibility for increased toxicity in this age group. The majority of patients with adequate performance status and without comorbidities precluding combined therapy should receive short-course radiotherapy (40 Gy in 15 fractions) with concurrent and adjuvant temozolomide. Patients with poor performance status and the frail elderly may be offered best supportive care, or treatment based on MGMT status: temozolomide monotherapy for patients with MGMT-methylated GBM or short-course radiotherapy alone for unmethylated GBM.

\section{Role of bevacizumab}

GBM is a highly vascular neoplasm, with abnormal vasculature characterized by tortuous blood vessels, vascular permeability and resulting hypoxia leading to the histological finding of pseudopalisading necrosis [31]. Tumor growth and invasion are intrinsically linked to hypoxia, which results in upregulation of hypoxia-inducible factor 1$\alpha$, and downstream upregulation of VEGF, which is associated with glioma cell stemness, mesenchymal phenotype and an immunosuppressive cellular milieu [32]. Thus, there is a strong biologic rationale for the use of antiangiogenic 
agents in GBM, and these drugs have thus been extensively studied as therapeutic targets in both newly diagnosed and recurrent GBM.

Bevacizumab, a humanized monoclonal antibody which binds VEGF-A, is the most extensively studied of the antiangiogenic agents for GBM. Bevacizumab was approved by the US FDA for use in recurrent GBM in 2009 [33]. The 'Bevacizumab Alone and in Combination with Irinotecan in Recurrent GBM' (BRAIN) study [34] was a randomized Phase II trial that assigned 167 patients with recurrent GBM to receive bevacizumab $10 \mathrm{mg} / \mathrm{kg}$ with or without irinotecan. This trial demonstrated objective response rates of 38 and $28 \%$ in patients treated with bevacizumab with and without irinotecan, respectively. Progression-free survival at 6 months (PFS-6) was 42\% in patients treated with bevacizumab alone and $50 \%$ in the combination arm. In a single-arm study, 48 patients with recurrent GBM were treated with bevacizumab $10 \mathrm{mg} / \mathrm{kg}$ with irinotecan added upon disease progression, demonstrating an objective response rate of 35\% and PFS-6 of 29\% [35]. While these findings led to FDA approval for recurrent GBM in the USA, its use has not been approved in Europe due to concerns regarding the lack of a bevacizumab-free control arm, the modest improvement in OS and difficulties with interpreting MRI-based disease progression in patients treated with bevacizumab [36].

In the USA, widespread use of bevacizumab for recurrent GBM has limited the opportunity for further evaluation in this setting. In Europe, the randomized Phase II 'Single-Agent Bevacizumab or Lomustine Versus a Combination of Bevacizumab Plus Lomustine in Patients with Recurrent GBM' (BELOB) trial [37] showed promising results for the combination of bevacizumab and lomustine versus either agent alone. Unfortunately, these findings were not borne out in the subsequent Phase III trial which compared the combination of lomustine and bevacizumab with lomustine alone [38]. This trial showed no difference in OS, although there was a significant increase in PFS from 1.5 to 4.2 months in the combination arm. Several other Phase II trials have evaluated the combination of bevacizumab with a variety of other cytotoxic and targeted agents, including temozolomide, temsirolimus and erlotinib, but none have shown significant activity [31].

Similarly, bevacizumab has been tested in the setting of newly diagnosed GBM, with a series of Phase II trials using bevacizumab in combination with radiotherapy and temozolomide [39-41]. As seen in the recurrent setting, PFS was prolonged in comparison to historical controls (13-14 months), while the effect on OS was modest (10-21 months). Subsequently, two randomized Phase III trials were conducted, 'A Study of Avastin in Combination With Temozolomide and Radiotherapy in Patients With Newly Diagnosed GBM' (AVAGlio) [42] and RTOG-0825 [43]. These studies showed longer PFS in patients treated with bevacizumab, but failed to show OS benefit. Thus, despite encouraging preclinical results with in vivo activity and reduction of vasogenic edema, there is abundant high-quality evidence that bevacizumab is not indicated in unselected patients with newly diagnosed GBM.

\section{Role of alternating electric fields}

The locoregional use of alternating electric fields to treat tumors, called TTF, represents a novel treatment modality [44]. Preclinical data showed that low-intensity $(1-3 \mathrm{~V} / \mathrm{cm})$, intermediate-frequency $(200 \mathrm{kHz})$ fields selectively disrupted microtubule assembly, thereby interfering with mitotic spindle formation and segregation of the two daughter cells during mitosis. This caused preferential apoptosis of rapidly dividing malignant cells. In contrast, lower frequencies caused undesirable depolarization of neurons and myocytes, and higher frequencies caused excess heat generation.

TTF is administered via transducer arrays, which are applied to the patient's shaved scalp for $18 \mathrm{~h}$ per day. The arrays are oriented to target the tumor volume based on contemporaneous imaging. The device is powered by a portable generator carried by the patient.

Two pivotal randomized Phase III trials have examined the efficacy of TTF in patients with GBM. The EF-11 trial [45] examined 237 patients with progressive GBM treated with either TTF or physician's choice of chemotherapy and failed to demonstrate improvement in PFS (median 2.2 vs 2.1 months; HR: 0.81 ; 95\% CI: $0.60-1.09$; $\mathrm{p}=0.16$ ) or OS (median 6.6 vs 6.0 months; HR: 0.86; 95\% CI: 0.66-1.12; $\mathrm{p}=0.27$ ).

The second study, the EF-14 trial [46], investigated 695 patients with newly diagnosed GBM who had already completed temozolomide chemoradiotherapy. The patients were recruited from 83 institutions internationally and their characteristics were comparable to contemporary Phase III trials of newly diagnosed GBM. They received either TTF and temozolomide, or temozolomide alone for 6-12 cycles. The primary endpoint was PFS, which improved from a median of 4.0-7.1 months (HR: 0.62; 98.7\% CI: 0.43-0.89; $\mathrm{p}=0.001$ ). In addition, OS in 
the intention-to-treat population improved from a median of 16.6-19.6 months (HR: 0.74; 95\% CI 0.56-0.98; $\mathrm{p}=0.03)$. This survival improvement was confirmed in preliminary reporting of the updated EF-14 results [47].

The predominant toxicities from TTF were local skin irritation and headache. Skin irritation was grade 1 or 2 in $43 \%$ of patients, and grade 3 in $2 \%$ of patients. Grade 1 or 2 headache was more frequently reported (TTF $21 \%$ vs control $14 \%$ ). No additional systemic toxicity was identified with TTF. It was reported that quality of life was not adversely affected, measured by EORTC QLQ C-30 and BN20 questionnaires, performance status and mini-mental examination scores [48]. However, in our opinion, these measures may not fully encompass the decisions involved in patient decision making, such as the perceived stigmatization and inconvenience of wearing the TTF device. Compliance was only $75 \%$ in the EF-14 trial, which involved highly motivated patients.

There are other considerations when interpreting the EF-14 trial. First, patients and investigators were not blinded. Patients randomized to TTF received additional training and support necessary for use of the TTF device. Together, these may have conferred a placebo benefit. Another qualification was that randomization was performed after successful completion of chemoradiotherapy, such that the benefit of TTF may not be applicable to patients with primary refractory disease.

Of note, the financial cost of TTF relative to its efficacy poses a major impediment to implementation. A cost-effectiveness analysis of TTF using a decision-analysis Markov model was reported based on the EF-14 results and unit cost of $€ 21,000$ per month [49]. The incremental cost-effectiveness ratio was $€ 549,909$ per life-year gained (95\% CI: 447,017-745,805). In Canada and many other countries, an intervention with incremental costeffectiveness ratio > CAD $\$ 100,000$ per life-year gained is typically viewed as poor resource utilization, although thresholds are frequently debated.

In summary, for newly diagnosed GBM, the EF-14 trial is supportive of TTF as being an efficacious treatment modality. However, the absolute benefit is modest and it does not meet established benchmarks for cost-effectiveness. For progressive GBM, there is insufficient evidence of benefit. The widespread adoption of TTF will therefore be contingent on identifying subgroups of patients with greatest benefit, and reduction in the market price of TTF to a commensurate level. Further studies are evaluating the utility of TTF for GBM, such as in combination with bevacizumab or stereotactic radiotherapy (NCT02663271, NCT02743078, NCT01894061, NCT01925573, NCT02343549).

\section{Novel therapies}

Immunotherapy in high-grade gliomas

The success of immune-based therapies in cancers such as melanoma and non-small-cell lung cancer (NSCLC), as well as other solid and hematologic malignancies, has led to a revolution in systemic cancer therapy. Clinical trials using these agents, which include immune checkpoint inhibitors, antitumor vaccines and autologous cell-based therapies, are ongoing for a wide variety of tumor types, including GBM.

While there is preclinical evidence to support activity of these agents in primary CNS malignancies, their use is complicated by both the unique immunologic milieu of the CNS and by the wide array of mechanisms used by high-grade gliomas to promote peritumoral immunosuppression and avoid immunologic surveillance. Within the CNS, access by activated T cells is limited by the glia limitans, a component of the blood-brain barrier [50], as well as the expression of Fas ligand, leading to apoptosis of Fas-expressing cytotoxic T-lymphocytes [51]. The tumor microenvironment of GBM is characterized by expression of immunosuppressive cytokines, such as TGF- $\beta$, IL-10, signal transducer and activator of transcription 3 and programmed-death ligand 1 [50-52]. In addition, systemic immune suppression is inherent in many patients with GBM, as evidenced by significant lymphopenia, and is likely exacerbated by lymphotoxic treatments such as radiation, temozolomide and corticosteroids $[50,53]$. For instance, treatment-induced lymphopenia has been associated with shorter OS in patients treated with standard chemoradiotherapy, and may also influence response to immune-based therapies [53]. It remains to be seen to what degree these factors will influence the efficacy of immunotherapy in primary CNS malignancies.

Antitumor vaccine therapy is one form of immunotherapy that has been extensively investigated in GBM. Broadly, these vaccines can be characterized as peptide- and cell-based vaccines, although there are many variations of each.

In peptide-based vaccination, patients are directly inoculated with one or more tumor-associated antigens in order to elicit an immune response against tumor cells. The peptide epitopes are selected based on immunogenicity, tumor specificity and homogeneity of expression. These proteins may be linked with carrier proteins to enhance 
immunogenicity, such as keyhole limpet hemocyanin, and are frequently administered with immune-stimulating adjuvants including granulocytic-macrophage colony-stimulating factor.

The most extensively evaluated vaccine-based therapy for glioma to date is rindopepimut, which consists of the amino acid sequence of EGFR variant III (EGFRvIII) conjugated to keyhole limpet hemocyanin. This primes dendritic cells against EGFRvIII, which then generates a specific immune response against GBM cells harboring the EGFRvIII mutation. Notably, this represents a combination of targeted and immunotherapeutic strategies. For patients with newly diagnosed GBM harboring the EGFRvIII mutation, trials evaluated the addition of rindopepimut to standard temozolomide chemoradiotherapy. In the Phase II ACT-III trial, median PFS and OS were 9.2 and 21.8 months, respectively, which were significantly longer than matched controls [54]. However, there was no survival benefit in the randomized Phase III ACT-IV trial when preliminary results were recently presented [55]. For patients with recurrent GBM harboring the EGFRvIII mutation, preliminary findings from the randomized Phase II ReACT trial showed significant OS improvement from 8.8 to 12.0 months with rindopepimut plus bevacizumab versus bevacizumab alone [56]. Of note, upon progression after treatment with rindopepimut, EGFRvIII expression was lost, although it is unknown whether this represents the natural evolution of disease or the results of immunologic selection.

Other vaccines targeting EGFRvIII are in early clinical testing, including ADU-623, which uses a live attenuated listeria vaccine targeting EGFRvIII in recurrent high-grade glioma (NCT01967758). Another target for peptide vaccines in glioma is IDH1, given that the IDH1 R132H mutation is expressed in the majority of secondary GBM and is thought to represent a driver mutation in glioma development. Phase I studies are underway (NCT02454634, NCT02193347, NCT02771301).

In cell-based vaccination, autologous antigen-presenting cells (APCs) such as dendritic cells are harvested from the patient and primed with one or more tumor-associated antigens. Antigen loading may be performed with one or more peptide epitopes, or harvested APCs may be exposed to a lysate of the patient's own tumor cells in order to generate a personalized vaccine. The primed APCs are then reintroduced to the patient, resulting in antigen-specific T-cell activation. Other targets for cell-based vaccine therapy include tumor-derived mRNA, glioma stem cells and virus-derived antigens. While cell-based vaccines offer a unique opportunity for highly personalized therapy, and potentially limited toxicity due to the specificity of the targeted antigens, these agents are expensive and laborintensive to produce. The process entails harvesting APCs through apheresis, culturing and differentiating the cells in vitro, priming through exposure to the desired antigen and preparation of the personalized vaccine. This presents challenges in terms of potentially unacceptable delays in treatment as well as cost-effectiveness concerns. To date, there are no reported Phase III trials of cell-based therapies, so clinical utility of these agents remains to be determined.

Immune checkpoint inhibition is another promising form of immunotherapy. There is preclinical evidence of their activity in murine models of glioma, as well as clinical responses in brain metastases of melanoma and NSCLC. Multiple clinical trials are underway using these agents both in newly diagnosed and recurrent GBM, and as monotherapy, dual checkpoint inhibition and combinations with other agents. Preliminary results of CheckMate143, a randomized Phase III trial using nivolumab in combination with bevacizumab in patients with recurrent GBM, were recently reported and showed no benefit of the nivolumab with bevacizumab combination over bevacizumab alone [57]. So far, responses in early phase studies suggest that the activity of these agents in GBM may be modest at best, in comparison to the dramatic responses observed in melanoma and NSCLC [58]. This may be related in part to the relatively low mutational burden of malignant glioma and the underlying immunosuppressive cellular milieu. Nonetheless, we await the forthcoming trial results to inform our decision making.

\section{Targeted therapies}

Targeted therapies represent a paradigm shift toward rational drug design. They selectively target signaling pathways, which are believed to be important for glioma growth and survival, based on our understanding of the fundamental processes driving malignancy [59]. The targeted therapy trials, which will be discussed, are summarized in Table 1.

The EGF receptor is overexpressed in many GBMs [97]. Early studies suggested that GBMs harboring a specific EGF receptor mutation (EGFRvIII) and intact phosphate and tensin homolog suppressor (PTEN) gene might respond favorably to EGF inhibition [98]. Numerous EGF receptor inhibitors were therefore evaluated in GBM trials, including the small molecule inhibitors gefitinib [60], erlotinib [62,64] and afatinib [65], and the monoclonal antibodies cetuximab [61], mAb 425 [63] and nimotuzumab [66]. Unfortunately, despite being a proven strategy in 
Table 1. Targeted therapies in high-grade gliomas.

\begin{tabular}{|c|c|c|c|c|c|c|}
\hline Study & Year & Setting & $\mathbf{N}$ & Design & Findings & Ref. \\
\hline \multicolumn{7}{|l|}{ EGF inhibition } \\
\hline Rich et al. & 2004 & $\begin{array}{l}\text { Recurrent } \\
\text { glioblastoma }\end{array}$ & 57 & $\begin{array}{l}\text { Phase II trial } \\
\text { Gefitinib 500-1000-mg daily }\end{array}$ & $\begin{array}{l}\text { ORR: } 0 \% \\
\text { PFS-6: } 13 \%\end{array}$ & [60] \\
\hline Neyns et al. & 2009 & $\begin{array}{l}\text { Recurrent } \\
\text { glioblastoma or } \\
\text { anaplastic } \\
\text { glioma }\end{array}$ & 55 & $\begin{array}{l}\text { Phase II trial } \\
\text { Cetuximab } 250 \mathrm{mg} / \mathrm{m}^{2} \text { weekly }\end{array}$ & $\begin{array}{l}\text { ORR: } 6 \% \\
\text { PFS-6: } 9 \%\end{array}$ & [61] \\
\hline van den Bent et al. & 2009 & $\begin{array}{l}\text { Recurrent } \\
\text { glioblastoma }\end{array}$ & 110 & $\begin{array}{l}\text { Phase II trial } \\
\text { 1. Erlotinib } 150-200-\mathrm{mg} \text { daily } \\
\text { 2. Temozolomide } 150-200 \mathrm{mg} / \mathrm{m}^{2} \\
\text { D1-5 q4w or carmustine } \\
60-80 \mathrm{mg} / \mathrm{m}^{2} \text { D } 1-3 \mathrm{q} 8 \mathrm{w}\end{array}$ & $\begin{array}{l}\text { ORR: } 4 \text { vs } 10 \% \\
\text { PFS-6: } 11 \text { vs } 24 \%\end{array}$ & {$[62]$} \\
\hline Li et al. & 2010 & $\begin{array}{l}\text { Newly } \\
\text { diagnosed } \\
\text { glioblastoma }\end{array}$ & 192 & $\begin{array}{l}\text { Phase II trial } \\
\text { Temozolomide } \\
\text { chemoradiotherapy }+ \text { mAb } 425\end{array}$ & mOS: $15.7 \mathrm{~m}$ & [63] \\
\hline Reardon et al. & 2015 & $\begin{array}{l}\text { Recurrent } \\
\text { glioblastoma }\end{array}$ & 119 & $\begin{array}{l}\text { Phase II trial } \\
\text { 1. Afatinib } 40 \mathrm{mg} \text { daily }+ \\
\text { temozolomide } 75 \mathrm{mg} / \mathrm{m}^{2} \mathrm{D} 1-21 \\
\mathrm{q} 4 \mathrm{w} \\
\text { 2. Afatinib } 40 \mathrm{mg} \text { daily } \\
\text { 3. Temozolomide } 75 \mathrm{mg} / \mathrm{m}^{2} \\
\text { D1-21 q4w }\end{array}$ & $\begin{array}{l}\text { ORR: } 14 \text { vs } 14 \text { vs } 21 \% \\
\text { PFS-6: } 10 \text { vs } 3 \text { vs } 23 \%\end{array}$ & [65] \\
\hline Westphal et al. & 2015 & $\begin{array}{l}\text { Newly } \\
\text { diagnosed } \\
\text { glioblastoma }\end{array}$ & 149 & $\begin{array}{l}\text { Phase III trial } \\
\text { 1. Temozolomide } \\
\text { chemoradiotherapy }+ \\
\text { nimotuzumab } \\
\text { 2. Temozolomide } \\
\text { chemoradiotherapy }\end{array}$ & $\begin{array}{l}\text { mPFS: } 7.7 \text { vs } 5.8 \mathrm{~m} \\
\text { mOS: } 22.3 \text { vs } 19.6 \mathrm{~m}\end{array}$ & [66] \\
\hline Reardon et al. & 2016 & $\begin{array}{l}\text { Newly } \\
\text { diagnosed } \\
\text { glioblastoma }\end{array}$ & 45 & $\begin{array}{l}\text { Phase I trial } \\
\text { Temozolomide } \\
\text { chemoradiotherapy + ABT- } 414\end{array}$ & $\begin{array}{l}\text { mPFS: } 6.1 \mathrm{~m} \\
\text { mOS: not reached }\end{array}$ & [68] \\
\hline \multicolumn{7}{|l|}{ EGF peptide vaccine } \\
\hline Schuster et al. & 2015 & $\begin{array}{l}\text { Newly } \\
\text { diagnosed } \\
\text { glioblastoma } \\
\text { expressing } \\
\text { EGFRvIll }\end{array}$ & 65 & $\begin{array}{l}\text { Phase II trial } \\
\text { Temozolomide } \\
\text { chemoradiotherapy }+ \\
\text { rindopepimut }\end{array}$ & $\begin{array}{l}\text { mPFS: } 9.2 \mathrm{~m} \\
\text { mOS: } 21.8 \mathrm{~m}\end{array}$ & [54] \\
\hline $\begin{array}{l}\text { Reardon et al. } \\
\text { (abstract) }\end{array}$ & 2015 & $\begin{array}{l}\text { Recurrent } \\
\text { glioblastoma } \\
\text { expressing } \\
\text { EGFRvill }\end{array}$ & 72 & $\begin{array}{l}\text { Phase II trial } \\
\text { 1. Rindopepimut }+ \text { bevacizumab } \\
\text { 2. Bevacizumab }\end{array}$ & $\begin{array}{l}\text { ORR: } 24 \text { vs } 17 \% \\
\text { PFS-6: } 27 \text { vs } 11 \% \\
\text { mOS: } 12.0 \text { vs } 8.8 \mathrm{~m}\end{array}$ & [56] \\
\hline Weller et al. (abstract) & 2016 & $\begin{array}{l}\text { Newly } \\
\text { diagnosed } \\
\text { glioblastoma } \\
\text { expressing } \\
\text { EGFRvIlI }\end{array}$ & 745 & $\begin{array}{l}\text { Phase III trial } \\
\text { 1. Temozolomide } \\
\text { chemoradiotherapy }+ \\
\text { rindopepimut } \\
\text { 2. Temozolomide } \\
\text { chemoradiotherapy }\end{array}$ & $\begin{array}{l}\text { Minimal residual disease } \\
\text { mOS: } 20.1 \text { vs } 20.0 \mathrm{~m} \\
\text { Nonminimal residual disease } \\
\text { mOS: } 14.8 \text { vs } 14.1 \mathrm{~m}\end{array}$ & [55] \\
\hline \multicolumn{7}{|l|}{ VEGF inhibition } \\
\hline Batchelor et al. & 2010 & $\begin{array}{l}\text { Recurrent } \\
\text { glioblastoma }\end{array}$ & 31 & $\begin{array}{l}\text { Phase II trial } \\
\text { Cediranib 45-mg daily }\end{array}$ & $\begin{array}{l}\text { ORR: } 27 \% \\
\text { PFS-6: } 26 \%\end{array}$ & [69] \\
\hline Iwamoto et al. & 2010 & $\begin{array}{l}\text { Recurrent } \\
\text { glioblastoma }\end{array}$ & 35 & $\begin{array}{l}\text { Phase II trial } \\
\text { Pazopanib } 800-m g \text { daily }\end{array}$ & $\begin{array}{l}\text { ORR: } 6 \% \\
\text { PFS-6: } 3 \%\end{array}$ & [70] \\
\hline
\end{tabular}

D\#: Day \#; EGFRvIII: EGFR variant III; m: Month; mAb: Monoclonal antibody; MGMT: O6-methylguanine-DNA methyltransferase; mOS: Median overall survival; mPFS: Median progression-free survival; N: Number; ORR: Objective response rate; PFS-6: Progression-free survival rate at 6 months; PTEN: Phosphate and tensin homolog; q8w: Every \# weeks; XPO: Exportin-1. 
Table 1. Targeted therapies in high-grade gliomas (cont.)

\begin{tabular}{|c|c|c|c|c|c|c|}
\hline Study & Year & Setting & N & Design & Findings & Ref. \\
\hline de Groot et al. & 2011 & $\begin{array}{l}\text { Recurrent } \\
\text { glioblastoma or } \\
\text { anaplastic } \\
\text { glioma }\end{array}$ & 58 & $\begin{array}{l}\text { Phase II trial } \\
\text { Aflibercept } 4 \mathrm{mg} / \mathrm{kg} \mathrm{q} 2 \mathrm{w}\end{array}$ & $\begin{array}{l}\text { Glioblastoma } \\
\text { ORR: } 18 \% \\
\text { PFS-6: } 8 \% \\
\text { Anaplastic glioma } \\
\text { ORR: } 44 \% \\
\text { PFS-6: } 25 \%\end{array}$ & [71] \\
\hline Pan et al. & 2012 & $\begin{array}{l}\text { Recurrent } \\
\text { glioblastoma or } \\
\text { anaplastic } \\
\text { glioma }\end{array}$ & 30 & $\begin{array}{l}\text { Phase II trial } \\
\text { Sunitinib 50-mg daily D1-28 q6w }\end{array}$ & $\begin{array}{l}\text { Glioblastoma } \\
\text { ORR: } 0 \% \\
\text { PFS-6: } 17 \% \\
\text { Anaplastic glioma } \\
\text { ORR: } 0 \% \\
\text { PFS-6: } 22 \%\end{array}$ & [72] \\
\hline Kreisl et al. & 2012 & $\begin{array}{l}\text { Recurrent } \\
\text { glioblastoma or } \\
\text { anaplastic } \\
\text { glioma }\end{array}$ & 64 & $\begin{array}{l}\text { Phase II trial } \\
\text { Vandetanib 300-mg daily }\end{array}$ & $\begin{array}{l}\text { Glioblastoma } \\
\text { ORR: } 13 \% \\
\text { PFS-6: } 7 \% \\
\text { Anaplastic glioma } \\
\text { ORR: } 7 \% \\
\text { PFS-6: } 7 \%\end{array}$ & [73] \\
\hline Muhic et al. & 2013 & $\begin{array}{l}\text { Recurrent } \\
\text { glioblastoma }\end{array}$ & 25 & $\begin{array}{l}\text { Phase II trial } \\
\text { Nintedanib } 200 \text { mg twice-daily }\end{array}$ & $\begin{array}{l}\text { ORR: } 0 \% \\
\text { PFS-6: } 4 \%\end{array}$ & [74] \\
\hline Reardon et al. & 2013 & $\begin{array}{l}\text { Recurrent } \\
\text { glioblastoma }\end{array}$ & 41 & $\begin{array}{l}\text { Phase II trial } \\
\text { Pazopanib } 400-\mathrm{mg} \text { daily + } \\
\text { lapatinib } 1000-\mathrm{mg} \text { daily }\end{array}$ & $\begin{array}{l}\text { PTEN/EGFRvIll positive } \\
\text { PFS-6: } 0 \% \\
\text { PTEN/EGFRvIII negative } \\
\text { PFS-6: } 15 \%\end{array}$ & [75] \\
\hline Kreisl et al. & 2013 & $\begin{array}{l}\text { Recurrent } \\
\text { glioblastoma }\end{array}$ & 63 & $\begin{array}{l}\text { Phase II trial } \\
\text { Sunitinib } 37.5-\mathrm{mg} \text { daily }\end{array}$ & $\begin{array}{l}\text { Bevacizumab naive } \\
\text { PFS-6: } 10 \% \\
\text { Bevacizumab resistant } \\
\text { PFS-6: } 0 \%\end{array}$ & [76] \\
\hline Batchelor et al. & 2013 & $\begin{array}{l}\text { Recurrent } \\
\text { glioblastoma }\end{array}$ & 325 & $\begin{array}{l}\text { Phase III trial } \\
\text { 1. Cediranib } 20-\mathrm{mg} \text { daily + } \\
\text { lomustine } 110 \mathrm{mg} / \mathrm{m}^{2} \mathrm{q} 6 \mathrm{w} \\
\text { 2. Cediranib } 30-\mathrm{mg} \text { daily } \\
\text { 3. Placebo + lomustine } \\
110 \mathrm{mg} / \mathrm{m}^{2} \mathrm{q} 6 \mathrm{w}\end{array}$ & $\begin{array}{l}\text { ORR: } 17 \text { vs } 15 \text { vs } 9 \% \\
\text { PFS-6: } 35 \text { vs } 25 \text { vs } 16 \\
\text { mPFS: } 4.1 \text { vs } 3.0 \text { vs } 2.7 \mathrm{~m} \\
\text { mOS: } 9.4 \text { vs } 8.0 \text { vs } 9.8 \mathrm{~m}\end{array}$ & [77] \\
\hline \multicolumn{7}{|l|}{ PDGF inhibition } \\
\hline Lassman et al. & 2011 & $\begin{array}{l}\text { Recurrent } \\
\text { glioblastoma } \\
\text { with } \\
\text { overexpression } \\
\text { of dasatinib } \\
\text { molecular } \\
\text { targets }\end{array}$ & 50 & $\begin{array}{l}\text { Phase II trial } \\
\text { Dasatinib } 100 \text { mg twice-daily }\end{array}$ & $\begin{array}{l}\text { ORR: } 0 \% \\
\text { PFS-6: } 6 \%\end{array}$ & [78] \\
\hline \multicolumn{7}{|l|}{ mTOR inhibition } \\
\hline Chang et al. & 2005 & $\begin{array}{l}\text { Recurrent } \\
\text { glioblastoma }\end{array}$ & 43 & $\begin{array}{l}\text { Phase II trial } \\
\text { Temsirolimus } 250-\mathrm{mg} \\
\text { intravenously weekly }\end{array}$ & $\begin{array}{l}\text { ORR: } 5 \% \\
\text { PFS-6: } 2 \%\end{array}$ & [79] \\
\hline Galanis et al. & 2005 & $\begin{array}{l}\text { Recurrent } \\
\text { glioblastoma }\end{array}$ & 65 & $\begin{array}{l}\text { Phase II trial } \\
\text { Temsirolimus } 250-\mathrm{mg} \\
\text { intravenously weekly }\end{array}$ & $\begin{array}{l}\text { ORR: } 36 \% \\
\text { PFS-6: } 8 \%\end{array}$ & [80] \\
\hline Kreisl et al. & 2009 & $\begin{array}{l}\text { Recurrent } \\
\text { glioblastoma }\end{array}$ & 22 & $\begin{array}{l}\text { Phase II trial } \\
\text { Everolimus } 70-\mathrm{mg} \text { weekly }+ \\
\text { gefitinib 250-mg daily }\end{array}$ & $\begin{array}{l}\text { ORR: } 14 \% \\
\text { PFS-6: } 0 \%\end{array}$ & [81] \\
\hline \multicolumn{7}{|l|}{ PI3K inhibition } \\
\hline Pitz et al. & 2015 & $\begin{array}{l}\text { Recurrent } \\
\text { glioblastoma }\end{array}$ & 33 & $\begin{array}{l}\text { Phase II trial } \\
\text { Sonolisib 8-mg daily }\end{array}$ & $\begin{array}{l}\text { ORR: } 3 \% \\
\text { PFS-6: } 17 \%\end{array}$ & [82] \\
\hline \multicolumn{7}{|l|}{ PKC inhibition } \\
\hline Kreisl et al. & 2010 & $\begin{array}{l}\text { Recurrent } \\
\text { glioblastoma or } \\
\text { anaplastic } \\
\text { glioma }\end{array}$ & 118 & $\begin{array}{l}\text { Phase II trial } \\
\text { Enzastaurin 500-525-mg daily }\end{array}$ & $\begin{array}{l}\text { Glioblastoma } \\
\text { ORR: } 30 \% \\
\text { PFS-6: } 7 \% \\
\text { Anaplastic glioma } \\
\text { ORR: } 15 \% \\
\text { PFS-6: } 16 \%\end{array}$ & [83] \\
\hline
\end{tabular}

D\#: Day \#; EGFRvIll: EGFR variant III; m: Month; mAb: Monoclonal antibody; MGMT: 06-methylguanine-DNA methyltransferase; mOS: Median overall survival; mPFS: Median progression-free survival; N: Number; ORR: Objective response rate; PFS-6: Progression-free survival rate at 6 months; PTEN: Phosphate and tensin homolog; q8w: Every \# weeks; XPO: Exportin-1. 
Table 1. Targeted therapies in high-grade gliomas (cont.)

\begin{tabular}{|c|c|c|c|c|c|c|}
\hline Study & Year & Setting & $\mathbf{N}$ & Design & Findings & Ref. \\
\hline Wick et al. & 2010 & $\begin{array}{l}\text { Recurrent } \\
\text { glioblastoma }\end{array}$ & 266 & $\begin{array}{l}\text { Phase III trial } \\
\text { 1. Enzastaurin } 500-\mathrm{mg} \text { daily q6w } \\
\text { 2. Lomustine } 100-130 \mathrm{mg} / \mathrm{m}^{2} \\
\text { q6w }\end{array}$ & $\begin{array}{l}\text { ORR: } 3 \text { vs } 4 \% \\
\text { PFS-6: } 11 \text { vs } 19 \% \\
\text { mPFS: } 1.5 \text { vs } 1.6 \mathrm{~m} \\
\text { mOS: } 6.6 \text { vs } 7.1 \mathrm{~m}\end{array}$ & [84] \\
\hline \multicolumn{7}{|l|}{ c-Met inhibition } \\
\hline Wen et al. (abstract) & 2010 & $\begin{array}{l}\text { Recurrent } \\
\text { glioblastoma }\end{array}$ & 124 & $\begin{array}{l}\text { Phase II trial } \\
\text { Cabozantinib 125-175-mg daily }\end{array}$ & PFS-6: $21 \%$ & [85] \\
\hline Wen et al. & 2011 & $\begin{array}{l}\text { Recurrent } \\
\text { glioblastoma }\end{array}$ & 61 & $\begin{array}{l}\text { Phase II trial } \\
\text { Rilotumumab } 10-20 \mathrm{mg} / \mathrm{kg} \text { q2w }\end{array}$ & ORR: $0 \%$ & [86] \\
\hline \multicolumn{7}{|l|}{ Integrin inhibition } \\
\hline Reardon et al. & 2008 & $\begin{array}{l}\text { Recurrent } \\
\text { glioblastoma }\end{array}$ & 81 & $\begin{array}{l}\text { Phase II trial } \\
\text { 1. Cilengitide } 500 \mathrm{mg} \\
\text { twice-weekly } \\
\text { 2. Cilengitide } 2000 \mathrm{mg} \\
\text { twice-weekly }\end{array}$ & $\begin{array}{l}\text { ORR: } 5 \text { vs } 13 \% \\
\text { PFS-6: } 10 \text { vs } 15 \%\end{array}$ & [87] \\
\hline Gilbert et al. & 2012 & $\begin{array}{l}\text { Recurrent } \\
\text { glioblastoma } \\
\text { undergoing } \\
\text { surgery }\end{array}$ & 30 & $\begin{array}{l}\text { Phase II trial } \\
\text { Cilengitide } 2000 \mathrm{mg} \\
\text { twice-weekly }\end{array}$ & PFS-6: $12 \%$ & [88] \\
\hline Stupp et al. & 2014 & $\begin{array}{l}\text { Newly } \\
\text { diagnosed } \\
\text { glioblastoma } \\
\text { with MGMT } \\
\text { promoter } \\
\text { methylation }\end{array}$ & 545 & $\begin{array}{l}\text { Randomized Phase III trial } \\
\text { 1. Temozolomide } \\
\text { chemoradiotherapy + cilengitide } \\
2000 \text { mg twice-weekly } \\
\text { 2. Temozolomide } \\
\text { chemoradiotherapy }\end{array}$ & $\begin{array}{l}\text { mPFS: } 13.5 \text { vs } 10.7 \mathrm{~m} \\
\text { mOS: } 26.3 \text { vs } 26.3 \mathrm{~m}\end{array}$ & [89] \\
\hline \multicolumn{7}{|l|}{ Microtubule inhibition } \\
\hline Stupp et al. & 2011 & $\begin{array}{l}\text { Recurrent } \\
\text { glioblastoma }\end{array}$ & 38 & $\begin{array}{l}\text { Phase II trial } \\
\text { Sagopilone } 16 \mathrm{mg} / \mathrm{m}^{2} \mathrm{q} 3 \mathrm{w}\end{array}$ & $\begin{array}{l}\text { ORR: } 0 \% \\
\text { PFS-6: } 7 \%\end{array}$ & [90] \\
\hline Chamberlain et al. & 2014 & $\begin{array}{l}\text { Recurrent } \\
\text { glioblastoma }\end{array}$ & 56 & $\begin{array}{l}\text { Phase II trial } \\
\text { Verubulin } 3.3 \mathrm{mg} / \mathrm{m}^{2} \mathrm{D} 1,8,15 \\
\text { q4w }\end{array}$ & $\begin{array}{l}\text { Bevacizumab naive } \\
\text { PFS-6: } 14 \% \\
\text { Bevacizumab resistant } \\
\text { PFS-6: } 8 \%\end{array}$ & [91] \\
\hline \multicolumn{7}{|c|}{ Histone deacetylase inhibition } \\
\hline Galanis et al. & 2009 & $\begin{array}{l}\text { Recurrent } \\
\text { glioblastoma }\end{array}$ & 66 & $\begin{array}{l}\text { Phase II trial } \\
\text { Vorinostat } 200 \text { mg twice-daily } \\
\text { D1-14 q3w }\end{array}$ & $\begin{array}{l}\text { ORR: } 3 \% \\
\text { PFS-6: } 15 \%\end{array}$ & [92] \\
\hline Friday et al. & 2012 & $\begin{array}{l}\text { Recurrent } \\
\text { glioblastoma }\end{array}$ & 37 & $\begin{array}{l}\text { Phase II trial } \\
\text { Vorinostat } 400-\mathrm{mg} \text { daily } \mathrm{D} 1-14 \\
\text { q3w + bortezomib } 1.3 \mathrm{mg} / \mathrm{m}^{2} \\
\text { D1, } 4,8,11 \mathrm{q} 3 \mathrm{w}\end{array}$ & $\begin{array}{l}\text { ORR: } 3 \% \\
\text { PFS-6: } 0 \%\end{array}$ & [93] \\
\hline Lee et al. & 2015 & $\begin{array}{l}\text { Recurrent } \\
\text { glioblastoma or } \\
\text { anaplastic } \\
\text { glioma }\end{array}$ & 39 & $\begin{array}{l}\text { Phase II trial } \\
\text { Panobinostat } 30 \mathrm{mg} \mathrm{D} 1,3,5 \\
\text { q2w + bevacizumab } 10 \mathrm{mg} / \mathrm{kg} \\
\mathrm{q} 2 \mathrm{w}\end{array}$ & $\begin{array}{l}\text { Glioblastoma } \\
\text { ORR: } 29 \% \\
\text { PFS-6: } 30 \% \\
\text { Anaplastic glioma } \\
\text { ORR: } 27 \% \\
\text { PFS-6: } 47 \%\end{array}$ & [94] \\
\hline \multicolumn{7}{|l|}{ TGF- $\beta$ inhibition } \\
\hline Brandes et al. & 2016 & $\begin{array}{l}\text { Recurrent } \\
\text { glioblastoma }\end{array}$ & 158 & $\begin{array}{l}\text { Phase II trial } \\
\text { 1. Galunisertib } 150 \mathrm{mg} \\
\text { twice-daily D1-14 q4w + } \\
\text { lomustine } 100-130 \mathrm{mg} / \mathrm{m}^{2} \mathrm{q} 6 \mathrm{w} \\
\text { 2. Galunisertib } 150 \mathrm{mg} \\
\text { twice-daily D1-14 q4w } \\
\text { 3. Placebo + lomustine } \\
100-130 \mathrm{mg} / \mathrm{m}^{2} \mathrm{q} 6 \mathrm{w}\end{array}$ & $\begin{array}{l}\text { ORR: } 1 \text { vs } 5 \text { vs } 0 \% \\
\text { PFS- } 6: 6 \text { vs } 15 \text { vs } 6 \% \\
\text { mPFS: } 2 \text { vs } 2 \text { vs } 2 \mathrm{~m} \\
\text { mOS: } 6.7 \text { vs } 8.0 \text { vs } 7.5 \mathrm{~m}\end{array}$ & [95] \\
\hline \multicolumn{7}{|l|}{ XPO inhibition } \\
\hline $\begin{array}{l}\text { Mau-Sørensen } \\
\text { (abstract) }\end{array}$ & 2016 & $\begin{array}{l}\text { Recurrent } \\
\text { glioblastoma }\end{array}$ & 35 & $\begin{array}{l}\text { Phase II trial } \\
\text { 1. Selinexor } 50 \mathrm{mg} / \mathrm{m}^{2} \\
\text { twice-daily } \times 3 \text {, then surgery } \\
\text { 2. Selinexor } 50 \mathrm{mg} / \mathrm{m}^{2} \text { twice-daily } \\
\text { 3. Selinexor } 60 \mathrm{mg} \text { twice-daily } \\
\text { 4. Selinexor } 80-\mathrm{mg} \text { daily }\end{array}$ & $\begin{array}{l}\text { Pooled results } \\
\text { ORR: } 11 \% \\
\text { PFS-6: } 15 \%\end{array}$ & [96] \\
\hline
\end{tabular}


NSCLC and other malignancies, results have consistently showed limited activity in GBM, even among those with EGF receptor amplification.

A novel approach to EGF inhibition is the use of antibody-drug conjugates such as ABT-414. The antibody component of ABT-414 effectively binds to mutant EGF receptors despite the blood-brain barrier, then delivers the cytotoxic drug component directly to the tumor cell. This obviates the pharmacokinetic challenges with conventional EGF receptor inhibition. There have been encouraging results from preliminary studies of ABT414 [67,68], and Phase III trials are now underway (NCT02573324, NCT02343406).

Another approach is the use of EGF peptide vaccines such as rindopepimut, and studies evaluating this vaccine in patients with GBM have been presented elsewhere in this review.

Since GBM is a highly vascular tumor, another group of targeted therapies have been developed against tumor angiogenesis. Important mediators of angiogenesis include VEGF, PDGF, mTOR, PI3K, PKC and hepatocyte growth factor (c-Met). Bevacizumab, a monoclonal antibody against VEGF, was discussed previously. Unfortunately, the vast armamentarium of other antiangiogenic agents targeting VEGF, PDGF, mTOR, PI3K, PKC and c-Met have uniformly failed to show an efficacy signal, and no reliable biomarkers have been identified to improve treatment selection [69-86].

Regarding novel drug targets, cilengitide is an integrin inhibitor, which mediates transmembrane interactions between cells and the surrounding stroma. Despite early suggestion of cilengitide activity in GBM with MGMT promoter methylation [87,88], there was no survival benefit in the larger randomized Phase III 'Cilengitide Combined With Standard Treatment for Patients With Newly Diagnosed GBM With Methylated MGMT Promoter' (CENTRIC) trial, so development was discontinued [89].

Sagopilone and verubulin target the microtubules, which are needed for cell division [90,91]. Vorinostat and panobinostat inhibit histone deacetylase, with the aim of reversing epigenetic changes associated with malignancy [9294]. Galunisertib inhibits TGF- $\beta$ receptor- 1 , which has been associated with several growth signaling pathways [95]. Selinexor is a selective inhibitor of exportin-1 (XPO), which causes accumulation of tumor suppressor proteins within the nucleus [96]. Discouragingly, all of these drugs lacked relevant activity when tested in patients with recurrent GBM.

Overall, targeted therapies have yet to demonstrate efficacy beyond standard cytotoxic chemotherapy. A consideration is whether adequate intratumoral drug concentrations are reached due to the blood-brain barrier, given presence of efflux transporters on the endothelial cells and limited passage of large-molecular-weight antibodies. The presence of intratumoral heterogeneity is another complicating factor, since only malignant cells bearing the relevant target will be affected. In addition, there are likely varying degrees of pathway redundancy, so that blockade of one pathway alone may be insufficient for cytotoxicity.

To further the development of effective targeted therapies, it is essential that the pharmacokinetic and pharmacodynamic properties of prospective drugs are fully characterized in GBM patients at an early stage. An example would be use of window-of-opportunity studies, whereby test doses of drug are administered preoperatively, then drug levels and proof of drug action can be evaluated in the resection specimen. It may be necessary for certain drugs to be administered via alternate routes such as direct intratumoral injection. Novel approaches will be required to circumvent intratumoral heterogeneity. Possibilities include drug conjugates or combinations with radiopharmaceuticals and immunotherapeutics, whereby we leverage bystander effect and the immune response to deal with adjacent tumor cells not bearing the relevant target. Finally, there is critical need for predictive biomarkers to select subgroups of patients to benefit from particular treatments. We anticipate the increased adoption of molecular sequencing of tumors, novel imaging such as magnetic resonance spectroscopy, and the development of radiomics-based imaging analysis will provide new opportunities for biomarker discovery.

\section{Conclusion \& future perspective}

Despite exhaustive efforts to investigate novel therapies, treatment options for high-grade glioma have not changed significantly in recent times. A limiting factor is that trials are often small and underpowered, or require lengthy periods of patient accrual and follow-up before meaningful results become available. Moving forward, it is essential that we take maximum advantage of our finite patient pool. First, we must renew our support of international, multicenter, collaborative trial efforts which offer the greatest opportunity for robust and generalizable information to inform clinical decision making. Second, we need to embrace innovative trial methodologies that will allow us to more rapidly and efficiently test novel therapies. An exemplar is the 'GBM Adaptive Global Innovative Learning Environment' (GBM AGILE), which will use an adaptive trial design founded on Bayesian statistics. Patients will 
be preferentially recruited to treatment arms showing signs of efficacy, whereas ineffective treatment arms will be rapidly discontinued and replaced by newer options. Biomarker testing will be integrated into the selection process. In so doing, we optimize our expenditure of time and resources to support novel therapies with the greatest potential.

To achieve the promise of highly personalized medicine, we need to build on our advances in molecular neuropathology. A commitment to biobank collection of surgical specimens will afford an essential and rich resource for this. We envisage that concerted efforts in genomic sequencing, proteomic analysis and methylation profiling of high-grade gliomas, coupled with advances in bioinformatics and machine learning to interpret this data, will provide the next important discoveries. Novel research should be encouraged, such as investigations into miRNAs, the tumor microenvironment, and the glymphatic and immune response. Beyond pathology, we anticipate integration of novel imaging biomarkers into the repertoire, driven by development of techniques such as magnetic resonance spectroscopy and radiomics-based imaging analysis.

Finally, we need to adapt new methods to counter the blood-brain barrier, tumor heterogeneity and treatment resistance. Innovative combinations of treatment modalities will present such opportunities. Neurosurgery provides valuable access to the peritumoral space. Targeted drug conjugates can selectively deliver cytotoxic chemotherapy, immunotherapeutics and radiopharmaceuticals directly to tumor cells. A vast suite of different immunotherapy approaches remain to be investigated. Sequencing of radiotherapy with immunotherapeutics can produce an abscopal effect, a concept which is being trialed in several solid tumor sites. All in all, treatments are limited only by our creative potential.

The future promises to be an era characterized by robust and efficient trial design, a resolute commitment to deciphering the key molecular neuropathology and an engagement with innovative combination therapy. Together, they offer a realistic prospect of ameliorating this devastating disease.

Financial \& competing interests disclosure

The authors have no relevant affiliations or financial involvement with any organization or entity with a financial interest in or financial conflict with the subject matter or materials discussed in the manuscript. This includes employment, consultancies, honoraria, stock ownership or options, expert testimony, grants or patents received or pending, or royalties.

No writing assistance was utilized in the production of this manuscript.

\section{Open access}

This work is licensed under the Creative Commons Attribution 4.0 License. To view a copy of this license, visit http://creativecommons.org/licenses/by/4.0/

\section{References}

Papers of special note have been highlighted as: $\bullet$ of interest; $\bullet \bullet$ of considerable interest

1. Stupp R, Mason WP, Van Den Bent MJ et al. Radiotherapy plus concomitant and adjuvant temozolomide for glioblastoma. N. Engl. J. Med. 352(10), 987-996 (2005).

2. Stupp R, Hegi ME, Mason WP et al. Effects of radiotherapy with concomitant and adjuvant temozolomide versus radiotherapy alone on survival in glioblastoma in a randomised Phase III study: 5-year analysis of the EORTC-NCIC trial. Lancet Oncol. 10(5), 459-466 (2009).

3. Van Den Bent MJ, Erridge S, Vogelbaum MA et al. Results of the interim analysis of the EORTC randomized Phase III CATNON trial on concurrent and adjuvant temozolomide in anaplastic glioma without $1 \mathrm{p} / 19 \mathrm{q}$ co-deletion: an intergroup trial. J. Clin. Oncol. 34(18_Suppl.), LBA2000-LBA2000 (2016).

4. Cairncross G, Wang M, Shaw E et al. Phase III trial of chemoradiotherapy for anaplastic oligodendroglioma: long-term results of RTOG 9402. J. Clin. Oncol. 31(3), 337-343 (2013).

5. Van Den Bent MJ, Brandes AA, Taphoorn MJ et al. Adjuvant procarbazine, lomustine, and vincristine chemotherapy in newly diagnosed anaplastic oligodendroglioma: long-term follow-up of EORTC brain tumor group study 26951. J. Clin. Oncol. 31(3), 344-350 (2013).

6. Dang L, White DW, Gross S et al. Cancer-associated IDH1 mutations produce 2-hydroxyglutarate. Nature 462(7274), 739-744 (2009).

7. Preusser M, Wohrer A, Stary S, Hoftberger R, Streubel B, Hainfellner JA. Value and limitations of immunohistochemistry and gene sequencing for detection of the IDH1-R132H mutation in diffuse glioma biopsy specimens. J. Neuropathol. Exp. Neurol. 70(8), 715-723 (2011).

8. Parsons DW, Jones S, Zhang X et al. An integrated genomic analysis of human glioblastoma multiforme. Science (New York, NY) 321(5897), 1807-1812 (2008). 
9. Hegi ME, Diserens AC, Gorlia T et al. MGMT gene silencing and benefit from temozolomide in glioblastoma. N. Engl. J. Med. 352(10), 997-1003 (2005).

10. Preusser M, Elezi L, Hainfellner JA. Reliability and reproducibility of PCR-based testing of O6-methylguanine-DNA methyltransferase gene (MGMT) promoter methylation status in formalin-fixed and paraffin-embedded neurosurgical biopsy specimens. Clin. Neuropathol. 27(6), 388-390 (2008).

11. Lalezari S, Chou AP, Tran A et al. Combined analysis of O6-methylguanine-DNA methyltransferase protein expression and promoter methylation provides optimized prognostication of glioblastoma outcome. Neuro Oncol. 15(3), 370-381 (2013).

12. Switzeny OJ, Christmann M, Renovanz M, Giese A, Sommer C, Kaina B. MGMT promoter methylation determined by HRM in comparison to MSP and pyrosequencing for predicting high-grade glioma response. Clin. Epigenetics 8, 49 (2016).

13. Bady P, Sciuscio D, Diserens AC et al. MGMT methylation analysis of glioblastoma on the Infinium methylation BeadChip identifies two distinct $\mathrm{CPG}$ regions associated with gene silencing and outcome, yielding a prediction model for comparisons across datasets, tumor grades, and CIMP-status. Acta Neuropathologica 124(4), 547-560 (2012).

14. Louis DN, Perry A, Reifenberger G et al. The 2016 World Health Organization Classification of Tumors of the Central Nervous System: a summary. Acta Neuropathologica 131(6), 803-820 (2016).

-. A fundamental summary of the principles and key changes adopted by the 5th Edition WHO Classification of Tumors of the Central Nervous System.

15. Sahm F, Reuss D, Koelsche C et al. Farewell to oligoastrocytoma: in situ molecular genetics favor classification as either oligodendroglioma or astrocytoma. Acta Neuropathol. 128(4), 551-559 (2014).

16. Coons SW, Johnson PC, Scheithauer BW, Yates AJ, Pearl DK. Improving diagnostic accuracy and interobserver concordance in the classification and grading of primary gliomas. Cancer 79(7), 1381-1393 (1997).

17. Kros JM, Gorlia T, Kouwenhoven MC et al. Panel review of anaplastic oligodendroglioma from European Organization For Research and Treatment of Cancer Trial 26951: assessment of consensus in diagnosis, influence of 1p/19q loss, and correlations with outcome. J. Neuropathol. Exp. Neurol. 66(6), 545-551 (2007).

18. Ostrom QT, Gittleman H, Liao P et al. CBTRUS statistical report: primary brain and central nervous system tumors diagnosed in the United States in 2007-2011. Neuro Oncol. 16(Suppl. 4), iv1-iv63 (2014).

19. Laperriere N, Weller M, Stupp R et al. Optimal management of elderly patients with glioblastoma. Cancer Treat. Rev. 39(4), 350-357 (2013).

20. Morgan ER, Norman A, Laing K, Seal MD. Treatment and outcomes for glioblastoma in elderly compared with non-elderly patients: a population-based study. Curr. Oncol. (Toronto, Ont.) 24(2), e92-e98 (2017).

21. Paszat L, Laperriere N, Groome P, Schulze K, Mackillop W, Holowaty E. A population-based study of glioblastoma multiforme. Int. J. Radiat. Oncol. Biol. Phys. 51(1), 100-107 (2001).

22. Brandes AA, Franceschi E, Tosoni A et al. Temozolomide concomitant and adjuvant to radiotherapy in elderly patients with glioblastoma: correlation with MGMT promoter methylation status. Cancer 115(15), 3512-3518 (2009).

23. Sijben AE, Mcintyre JB, Roldan GB et al. Toxicity from chemoradiotherapy in older patients with glioblastoma multiforme. J. Neurooncol. 89(1), 97-103 (2008).

24. Wiestler B, Claus R, Hartlieb SA et al. Malignant astrocytomas of elderly patients lack favorable molecular markers: an analysis of the NOA-08 study collective. Neuro Oncol. 15(8), 1017-1026 (2013).

25. Keime-Guibert F, Chinot O, Taillandier L et al. Radiotherapy for glioblastoma in the elderly. N. Engl. J. Med. 356(15), 1527-1535 (2007).

26. Roa W, Brasher PM, Bauman G et al. Abbreviated course of radiation therapy in older patients with glioblastoma multiforme: a prospective randomized clinical trial. J. Clin. Oncol. 22(9), 1583-1588 (2004).

27. Malmstrom A, Gronberg BH, Marosi C et al. Temozolomide versus standard 6-week radiotherapy versus hypofractionated radiotherapy in patients older than 60 years with glioblastoma: the Nordic randomised, Phase 3 trial. Lancet Oncol. 13(9), 916-926 (2012).

28. Wick W, Platten M, Meisner C et al. Temozolomide chemotherapy alone versus radiotherapy alone for malignant astrocytoma in the elderly: the NOA-08 randomised, Phase 3 trial. Lancet Oncol. 13(7), 707-715 (2012).

29. Gallego Perez-Larraya J, Ducray F, Chinot O et al. Temozolomide in elderly patients with newly diagnosed glioblastoma and poor performance status: an ANOCEF Phase II trial. J. Clin. Oncol. 29(22), 3050-3055 (2011).

30. Perry JR, Laperriere N, O'Callaghan CJ et al. Short-course radiation plus temozolomide in elderly patients with glioblastoma. N. Engl. J. Med. 376(11), 1027-1037 (2017).

•• EORTC 26062/22061-NCIC CTG CE6: practice-changing randomized Phase III trial of chemoradiotherapy in elderly patients with glioblastoma.

31. Wang N, Jain RK, Batchelor TT. New directions in anti-angiogenic therapy for glioblastoma. Neurotherapeutics 14(2), 321-332 (2017).

32. Lu-Emerson C, Duda DG, Emblem KE et al. Lessons from anti-vascular endothelial growth factor and anti-vascular endothelial growth factor receptor trials in patients with glioblastoma. J. Clin. Oncol. 33(10), 1197-1213 (2015). 
33. Cohen MH, Shen YL, Keegan P, Pazdur R. FDA drug approval summary: bevacizumab (Avastin) as treatment of recurrent glioblastoma multiforme. Oncologist 14(11), 1131-1138 (2009).

34. Friedman HS, Prados MD, Wen PY et al. Bevacizumab alone and in combination with irinotecan in recurrent glioblastoma. J. Clin. Oncol. 27(28), 4733-4740 (2009).

35. Kreisl TN, Kim L, Moore K et al. Phase II trial of single-agent bevacizumab followed by bevacizumab plus irinotecan at tumor progression in recurrent glioblastoma. J. Clin. Oncol. 27(5), 740-745 (2009).

36. Wick W, Weller M, Van Den Bent M, Stupp R. Bevacizumab and recurrent malignant gliomas: a European perspective. J. Clin. Oncol. 28(12), e188-e189; author reply e190-e182 (2010).

37. Taal W, Oosterkamp HM, Walenkamp AM et al. Single-agent bevacizumab or lomustine versus a combination of bevacizumab plus lomustine in patients with recurrent glioblastoma (BELOB trial): a randomised controlled Phase 2 trial. Lancet Oncol. 15(9), 943-953 (2014).

38. Wick W, Brandes AA, Gorlia T et al. EORTC 26101 Phase III trial exploring the combination of bevacizumab and lomustine in patients with first progression of a glioblastoma. J. Clin. Oncol. 34(15 Suppl.), 2001-2001 (2016).

39. Lai A, Tran A, Nghiemphu PL et al. Phase II study of bevacizumab plus temozolomide during and after radiation therapy for patients with newly diagnosed glioblastoma multiforme. J. Clin. Oncol. 29(2), 142-148 (2011).

40. Vredenburgh JJ, Desjardins A, Kirkpatrick JP et al. Addition of bevacizumab to standard radiation therapy and daily temozolomide is associated with minimal toxicity in newly diagnosed glioblastoma multiforme. Int. J. Radiat. Oncol. Biol. Phys. 82(1), 58-66 (2012).

41. Vredenburgh JJ, Desjardins A, Reardon DA et al. The addition of bevacizumab to standard radiation therapy and temozolomide followed by bevacizumab, temozolomide, and irinotecan for newly diagnosed glioblastoma. Clin. Cancer Res. 17(12), 4119-4124 (2011).

42. Chinot OL, Wick W, Mason W et al. Bevacizumab plus radiotherapy-temozolomide for newly diagnosed glioblastoma. N. Engl. J. Med. 370(8), 709-722 (2014).

- AVAGlio: Phase III randomized trial of bevacizumab in newly diagnosed glioblastoma showing lack of efficacy.

43. Gilbert MR, Dignam JJ, Armstrong TS et al. A randomized trial of bevacizumab for newly diagnosed glioblastoma. N. Engl. J. Med. 370(8), 699-708 (2014).

- RTOG-0825: Phase III randomized trial of bevacizumab in newly diagnosed glioblastoma showing lack of efficacy.

44. Hottinger AF, Pacheco P, Stupp R. Tumor treating fields: a novel treatment modality and its use in brain tumors. Neuro Oncol. 18(10), 1338-1349 (2016).

45. Stupp R, Wong ET, Kanner AA et al. NovoTTF-100A versus physician's choice chemotherapy in recurrent glioblastoma: a randomised Phase III trial of a novel treatment modality. Eur. J. Cancer 48(14), 2192-2202 (2012).

46. Stupp R, Taillibert S, Kanner AA et al. Maintenance therapy with tumor-treating fields plus temozolomide vs temozolomide alone for glioblastoma: a randomized clinical trial. JAMA 314(23), 2535-2543 (2015).

- EF14: Phase III randomized trial of tumor-treating fields in newly diagnosed glioblastoma; the first treatment to confer overall survival benefit in over a decade.

47. Stupp R, Hegi ME, Idbaih A et al. Abstract CT007: tumor treating fields added to standard chemotherapy in newly diagnosed glioblastoma (GBM): final results of a randomized, multi-center, Phase III trial. Presented at: American Association for Cancer Research. Annual Meeting 2017. WA, DC, USA, 1-5 April 2017.

48. Zhu J-J, Pannullo S, Mehdorn M et al. Quality of life, cognitive function and functional status in the EF-14 trial: a prospective, multi-center trial of TTFields wih temozolomide compared with temozolomide alone in patients with newly diagnosed GBM. Neuro Oncol. 17(Suppl. 5), v9-v9 (2015).

49. Bernard-Arnoux F, Lamure M, Ducray F, Aulagner G, Honnorat J, Armoiry X. The cost-effectiveness of tumor-treating fields therapy in patients with newly diagnosed glioblastoma. Neuro Oncol. 18(8), 1129-1136 (2016).

- A key counter argument to the widespread use of tumor-treating fields.

50. Reardon DA, Wen PY, Wucherpfennig KW, Sampson JH. Immunomodulation for glioblastoma. Curr. Opin. Neurol. 30(3), 361-369 (2017).

51. Engelhardt B, Vajkoczy P, Weller RO. The movers and shapers in immune privilege of the CNS. Nat. Immunol. 18(2), 123-131 (2017).

52. Tan AC, Heimberger AB, Khasraw M. Immune checkpoint inhibitors in gliomas. Curr. Oncol. Rep. 19(4), 23 (2017).

53. Yovino $S$, Grossman SA. Severity, etiology and possible consequences of treatment-related lymphopenia in patients with newly diagnosed high-grade gliomas. CNS Oncol. 1(2), 149-154 (2012).

54. Schuster J, Lai RK, Recht LD et al. A Phase II, multicenter trial of rindopepimut (CDX-110) in newly diagnosed glioblastoma: the ACT III study. Neuro Oncol. 17(6), 854-861 (2015).

55. Weller M, Butowski N, Tran D et al. ACT IV: an international, double-blind, Phase 3 trial of rindopepimut in newly diagnosed, EGFRvIII-expressing glioblastoma. Neuro Oncol. 18(Suppl. 6), vi17-vi18 (2016).

56. Reardon DA, Schuster J, Tran DD et al. ReACT: overall survival from a randomized Phase II study of rindopepimut (CDX-110) plus bevacizumab in relapsed glioblastoma. J. Clin. Oncol. 33(15 Suppl.), 2009-2009 (2015). 
57. Reardon DA, Omuro A, Brandes AA et al. Randomized Phase 3 study evaluating the efficacy and safety of nivolumab vs bevacizumab in patients with recurrent glioblastoma: CheckMate 143. Neuro Oncol. 19(Suppl. 3), iii21-iii21 (2017).

58. Sampson JH, Maus MV, June CH. Immunotherapy for brain tumors. J. Clin. Oncol. 35(21), 2450-2456 (2017).

59. Hanahan D, Weinberg RA. Hallmarks of cancer: the next generation. Cell 144(5), 646-674 (2011).

60. Rich JN, Reardon DA, Peery T et al. Phase II trial of gefitinib in recurrent glioblastoma. J. Clin. Oncol. 22(1), 133-142 (2004).

61. Neyns B, Sadones J, Joosens E et al. Stratified Phase II trial of cetuximab in patients with recurrent high-grade glioma. Ann. Oncol. 20(9), 1596-1603 (2009).

62. Van Den Bent MJ, Brandes AA, Rampling R et al. Randomized Phase II trial of erlotinib versus temozolomide or carmustine in recurrent glioblastoma: EORTC brain tumor group study 26034. J. Clin. Oncol. 27(8), 1268-1274 (2009).

63. Li L, Quang TS, Gracely EJ et al. A Phase II study of anti-epidermal growth factor receptor radioimmunotherapy in the treatment of glioblastoma multiforme. J. Neurosurg. 113(2), 192-198 (2010).

64. Peereboom DM, Ahluwalia MS, Ye X et al. NABTT 0502: a Phase II and pharmacokinetic study of erlotinib and sorafenib for patients with progressive or recurrent glioblastoma multiforme. Neuro Oncol. 15(4), 490-496 (2013).

65. Reardon DA, Nabors LB, Mason WP et al. Phase I/randomized Phase II study of afatinib, an irreversible ErbB family blocker, with or without protracted temozolomide in adults with recurrent glioblastoma. Neuro Oncol. 17(3), 430-439 (2015).

66. Westphal M, Heese O, Steinbach JP et al. A randomised, open label Phase III trial with nimotuzumab, an anti-epidermal growth factor receptor monoclonal antibody in the treatment of newly diagnosed adult glioblastoma. Eur. J. Cancer 51(4), 522-532 (2015).

67. Gan HK, Fichtel L, Lassman AB et al. A Phase 1 study evaluating ABT-414 in combination with temozolomide (TMZ) for subjects with recurrent or unresectable glioblastoma (GBM). J. Clin. Oncol. 32(15 Suppl.), 2021-2021 (2014).

68. Reardon DA, Lassman AB, Van Den Bent M et al. Efficacy and safety results of ABT-414 in combination with radiation and temozolomide in newly diagnosed glioblastoma. Neuro Oncol. 19(7), 965-975 (2016).

69. Batchelor TT, Duda DG, Di Tomaso E et al. Phase II study of cediranib, an oral pan-vascular endothelial growth factor receptor tyrosine kinase inhibitor, in patients with recurrent glioblastoma. J. Clin. Oncol. 28(17), 2817-2823 (2010).

70. Iwamoto FM, Lamborn KR, Robins HI et al. Phase II trial of pazopanib (GW786034), an oral multi-targeted angiogenesis inhibitor, for adults with recurrent glioblastoma (North American Brain Tumor Consortium Study 06-02). Neuro Oncol. 12(8), 855-861 (2010).

71. De Groot JF, Lamborn KR, Chang SM et al. Phase II study of aflibercept in recurrent malignant glioma: a North American Brain Tumor Consortium Study. J. Clin. Oncol. 29(19), 2689-2695 (2011).

72. Pan E, Yu D, Yue B et al. A prospective Phase II single-institution trial of sunitinib for recurrent malignant glioma. J. Neurooncol. 110(1), $111-118$ (2012).

73. Kreisl TN, Mcneill KA, Sul J, Iwamoto FM, Shih J, Fine HA. A Phase I/II trial of vandetanib for patients with recurrent malignant glioma. Neuro Oncol. 14(12), 1519-1526 (2012).

74. Muhic A, Poulsen HS, Sorensen M, Grunnet K, Lassen U. Phase II open-label study of nintedanib in patients with recurrent glioblastoma multiforme. J. Neurooncol. 111(2), 205-212 (2013).

75. Reardon DA, Groves MD, Wen PY et al. A Phase I/II trial of pazopanib in combination with lapatinib in adult patients with relapsed malignant glioma. Clin. Cancer Res. 19(4), 900-908 (2013).

76. Kreisl TN, Smith P, Sul J et al. Continuous daily sunitinib for recurrent glioblastoma. J. Neuroncol. 111(1), 41-48 (2013).

77. Batchelor TT, Mulholland P, Neyns B et al. Phase III randomized trial comparing the efficacy of cediranib as monotherapy, and in combination with lomustine, versus lomustine alone in patients with recurrent glioblastoma. J. Clin. Oncol. 31(26), 3212-3218 (2013).

78. Lassman AB, Pugh SL, Gilbert MR et al. Phase 2 trial of dasatinib in target-selected patients with recurrent glioblastoma (RTOG 0627). Neuro Oncol. 17(7), 992-998 (2015).

79. Chang SM, Wen P, Cloughesy T et al. Phase II study of CCI-779 in patients with recurrent glioblastoma multiforme. Invest. New Drugs 23(4), 357-361 (2005).

80. Galanis E, Buckner JC, Maurer MJ et al. Phase II trial of temsirolimus (CCI-779) in recurrent glioblastoma multiforme: a North Central Cancer Treatment Group Study. J. Clin. Oncol. 23(23), 5294-5304 (2005).

81. Kreisl TN, Lassman AB, Mischel PS et al. A pilot study of everolimus and gefitinib in the treatment of recurrent glioblastoma (GBM). J. Neurooncol. 92(1), 99-105 (2009).

82. Pitz MW, Eisenhauer EA, Macneil MV et al. Phase II study of PX-866 in recurrent glioblastoma. Neuro Oncol. 17(9), 1270-1274 (2015).

83. Kreisl TN, Kotliarova S, Butman JA et al. A Phase I/II trial of enzastaurin in patients with recurrent high-grade gliomas. Neuro Oncol. 12(2), 181-189 (2010).

84. Wick W, Puduvalli VK, Chamberlain MC et al. Phase III study of enzastaurin compared with lomustine in the treatment of recurrent intracranial glioblastoma. J. Clin. Oncol. 28(7), 1168-1174 (2010).

85. Wen PY, Prados M, Schiff D et al. Phase II study of XL184 (BMS 907351), an inhibitor of MET, VEGFR2, and RET, in patients (pts) with progressive glioblastoma (GB). J. Clin. Oncol. 28(15 Suppl.), 2006-2006 (2010). 
86. Wen PY, Schiff D, Cloughesy TF et al. A Phase II study evaluating the efficacy and safety of AMG 102 (rilotumumab) in patients with recurrent glioblastoma. Neuro Oncol. 13(4), 437-446 (2011).

87. Reardon DA, Fink KL, Mikkelsen T et al. Randomized Phase II study of cilengitide, an integrin-targeting arginine-glycine-aspartic acid peptide, in recurrent glioblastoma multiforme. J. Clin. Oncol. 26(34), 5610-5617 (2008).

88. Gilbert MR, Kuhn J, Lamborn KR et al. Cilengitide in patients with recurrent glioblastoma: the results of NABTC 03-02, a Phase II trial with measures of treatment delivery. J. Neurooncol. 106(1), 147-153 (2012).

89. Stupp R, Hegi ME, Gorlia T et al. Cilengitide combined with standard treatment for patients with newly diagnosed glioblastoma with methylated MGMT promoter (CENTRIC EORTC 26071-22072 study): a multicentre, randomised, open-label, Phase 3 trial. Lancet Oncol. 15(10), 1100-1108 (2014).

90. Stupp R, Tosoni A, Bromberg JE et al. Sagopilone (ZK-EPO, ZK 219477) for recurrent glioblastoma. A Phase II multicenter trial by the European Organisation for Research and Treatment of Cancer (EORTC) Brain Tumor Group. Ann. Oncol. 22(9), 2144-2149 (2011).

91. Chamberlain MC, Grimm S, Phuphanich S et al. A Phase 2 trial of verubulin for recurrent glioblastoma: a prospective study by the Brain Tumor Investigational Consortium (BTIC). J. Neurooncol. 118(2), 335-343 (2014).

92. Galanis E, Jaeckle KA, Maurer MJ et al. Phase II trial of vorinostat in recurrent glioblastoma multiforme: a north central cancer treatment group study. J. Clin. Oncol. 27(12), 2052-2058 (2009).

93. Friday BB, Anderson SK, Buckner J et al. Phase II trial of vorinostat in combination with bortezomib in recurrent glioblastoma: a north central cancer treatment group study. Neuro Oncol. 14(2), 215-221 (2012).

94. Lee EQ, Reardon DA, Schiff D et al. Phase II study of panobinostat in combination with bevacizumab for recurrent glioblastoma and anaplastic glioma. Neuro Oncol. 17(6), 862-867 (2015).

95. Brandes AA, Carpentier AF, Kesari S et al. A Phase II randomized study of galunisertib monotherapy or galunisertib plus lomustine compared with lomustine monotherapy in patients with recurrent glioblastoma. Neuro Oncol. 18(8), 1146-1156 (2016).

96. Mau-Sørensen M, Plotkin SR, Wen PY et al. A Phase 2 study on efficacy, safety and intratumoral pharmacokinetics of oral selinexor (KPT-330) in patients with recurrent glioblastoma (GBM). J. Clin. Oncol. 34(15 Suppl.), 2077-2077 (2016).

97. Rao SK, Edwards J, Joshi AD, Siu IM, Riggins GJ. A survey of glioblastoma genomic amplifications and deletions. J. Neurooncol. 96(2), 169-179 (2010).

98. Mellinghoff IK, Wang MY, Vivanco I et al. Molecular determinants of the response of glioblastomas to EGFR kinase inhibitors. N. Engl. J. Med. 353(19), 2012-2024 (2005). 